\title{
Implications From A Microarray Analysis: Solute Carrier Proteins May Be Potential Targets to Combat Stemness of Breast Cancer
}

\section{Mikrodizin Analizinden Bulgular: SLC Taşıyıcı Proteinleri, Meme Kanseri Kök Hücreleriyle Mücadelede Potansiyel Hedefler Olabilir}

\section{Meltem Demirel Kars}

Meram Vocational School, Depart. of Herbal and Animal Production, Medicinal and Aromatic Plants Program, Necmettin Erbakan University, Konya.

\section{ABSTRACT}

Self renewal of cancer stem cells, intrinsic and/or acquired drug resistance are the main factors preventing the anticancer therapy strategies for breast cancer. There are progressing studies to develop new therapeutic agents and to investigate the biomarker molecules to be targeted. In this study, a cDNA microarray analysis was performed in anticancer drug-paclitaxel resistant breast cancer cell line, which expresses the properties of breast cancer stem cells (BCSC). The drug sensitive parental MCF-7 cell line was used as control group. The genes overexpressed in BCSC-like cells that encode solute carrier (SLC) proteins were analyzed. According to the results, 21 SLC protein encoding genes were upregulated in the range of 2.0 and 35 folds. The genes, SLC38A5, SLC43A3, SLC6A15, SLC1A1, SLC2A3, SLC26A2, SLC22A15 and SLC16A3 are overexpressed about 9-35 folds. So, the related proteins may be regarded as potential targets and this will open a new research venue for the discovery of biomarkers to target breast cancer stem cells.

\section{Key Words}

Solute carrier proteins, microarray, breast cancer stem cells, drug resistance.

\section{öz}

M eme kanseri kök hücrelerinin kendi kendini yenilemesi, kendiliğinden olan ve sonradan kazanılan ilaç direnci, meme kanserinin tedavisi stratejilerini önleyen ana faktörlerdir. Yeni terapötik ajanlar geliştirmek için yapılan çalışmalarda hedeflenecek olan biyobelirteç molekülleri araştırılmaktadır. Bu çalışmada, meme kanseri kök hücrelerinin (MKKH) özelliklerini taşıyan, antikanser ilaç-paklitaksele dirençli meme kanseri hücre hattında tüm genom cDNA mikrodizin analizi yapılmıştır. Illaca duyarlı parental MCF-7 hücre hattı kontrol grubu olarak kullanılmıştır. MKKH benzeri hücrelerde solute carrier (SLC) taşıyıcı proteinleri kodlayan ve aşırı ifade edilen genler analiz edilmiştir. Elde edilen sonuçlara göre, 21 adet SLC proteini kodlayan genlerin ifade düzeyleri 2.0 ve 35 kat arasında artmıştır. SLC38A5, SLC43A3, SLC6A15, SLC1A1, SLC2A3, SLC26A2, SLC22A15, SLC16A3 genlerinin ifade düzeyleri 9 ile 35 kat arasında artmıştır. Dolayısıyla, ilgili proteinler potansiyel hedefler olarak kabul edilebilir ve bu bilgiler, meme kanseri kök hücrelerini hedef alan biyobelirteçlerin keşfedilmesi için yeni bir araştırma alanı açacaktır.

\section{Anahtar Kelimeler}

SLC taşıyıcı proteinler, mikrodizin, meme kanseri kök hücreleri, ilaç dirençliliği.

Article History: Received: Feb 19, 2019; Revised: Dec 16, 2019; Accepted: Dec 20, 2019; Available Online: Apr 1, 2020.

DOI: $\underline{\text { https://doi.org/10.15671/hibc.526094 }}$

Correspondence to: M.D. Kars, Meram Vocational School, Necmettin Erbakan University, Konya, Turkey.

E-Mail: dmeltem@yahoo.com 


\section{INTRODUCTION}

$\mathrm{M}$ embrane transporters are very important players of the cell signaling and trafficking. IUBMB, the International Union of Biochemistry and Molecular Biology, is highly interested in nomenclature of enzymes and proteins. According to IUBMB, membrane transport proteins are classified in seven groups. The carrier proteins that transport various solutes like charged and uncharged molecules and inorganic ions are generally called as SLC proteins. This transporter group contains 65 families and 400 family members [1]. SLCs involve crucial pharmacological pathways to transport drugs through cell membranes and to absorb drugs from intestine lumen [2]. So, as the roles and substrates of solute carrier proteins were identified, they gained importance in drug design studies. SLCs may be utilized as parameters for specific drug transport to the target cancer tissue.

Drug resistance developed during cancer therapy is the main obstacle of successful treatment. Increased anti-cancer drug efflux through ATP binding transmembrane proteins $(A B C)$ is the most dominating reason of multidrug resistance (MDR). Resistance of cancer stem cells and endurance of the cells even against combined therapy is the big challenge that the medical oncologists try to tackle with. Over-expression or inactivation of solute carrier encoding genes is another reason for impaired drug delivery in to the cancer cells [3]. The bases of drug resistance in paclitaxel treated breast cancer cell-line were exhibited in multiple papers by Kars et al. [4-7]. The paclitaxel resistant cell-line bears the features of breast cancer stem cells.

The elevations in the SLC protein encoding gene expression levels were demonstrated in this study. The SLC encoding genes were listed from a whole genome microarray data. It was found that 21 genes were upregulated in BCSC-like cells. The changes in gene expression levels may have implications that solute carrier proteins may be potential targets to combat stemness of breast cancer.

\section{MATERIALS and METHODS}

\section{Cell-lines and culturing}

MCF-7 cell line, the parental cell line that responds to chemotherapy by anticancer agents (MCF-7/S) and drug resistant MCF-7 cell line that is profoundly resistant to paclitaxel, MCF-7/Pac developed previously $[4,8]$ were used in this study. The microarray analysis was previously conducted for both drug responsive and paclitaxel resistant cell lines and some of the findings were reported previously $[5,6,9]$. The results of microarray analysis conducted by Human Genome U133 Plus (49/64), MCF-7/Pac exhibits markers of breast cancer stem cell which were established in practice $[10,11]$. cDNA microarray and protein array findings that we reported previously demonstrated that MCF-7/Pac cells posses the breast cancer stem cell-like properties. Also it was recently confirmed that drug resistant cancer cell population includes significant percentage of cells with breast cancer stem cell like features. Taking these facts as the basis, paclitaxel resistant cell population was assumed as BCSC-like cell model. Accordingly the cDNA microarray results of paclitaxel resistant cells are attributed to BCSC-like cells in this study. The cells were cultured in RPMI 1640 medium supplied with antibiotics for prevention of contamination and incubated in a carbon dioxide supplied cell culture incubator.

\section{Isolation of total RNA and synthesis of complement DNA}

TRI Reagent (Sigma) was used to isolate total RNA from sensitive and BCSC-like cells. Total RNA quality was measured by spectrophotometrically from the OD260nm/ OD280nm ratio and total RNA concentration was at least 2.5 micrograms per micro liters. The RNA integrity was also observed after gel electrophoresis. RNA isolation was repeated for each group to continue with the best two RNAs for each cell line (sensitive and drug resistant breast cancer cells). cDNA was synthesized by cDNA synthesis kit and in-vitro transcription from CDNA was performed to produce cRNAs and to label them with biotin (Affymetrix, USA). Finally labeled cRNAs were fragmented by incubating with magnesium solution. The fragmented and labelled cRNAs were prepared for hybridization process according to the manufacturer's prescription.

\section{Hybridization of gene chips and scanning the arrays}

Labelled and fragmented CRNA samples were mixed with un-labelled control RNA samples. The samples were loaded in to whole Genome U133 Plus 2.0 GeneChips. The samples were left for hybridization in rotating oven for $17 \mathrm{~h}$ (at $45^{\circ} \mathrm{C}, 60 \mathrm{rpm}$ revolution speed). The arrays were washed in Affymetrics Fluids Equipment. Finally, four GeneChips (two repeats for each cell line) were scanned in GeneChip scanner. 


\section{Analysis of cDNA microarray data}

The fluorescent data were analyzed by a quality control test and then the data were processed through robust multiarray average analysis. Finally Gene Spring (Agilent) software was employed for advanced data curation and analysis. The Student's t-test was applied to select the significant alterations expression levels of the genes BCSC-like cells with respect to drug responsive cells. The data was filtered so that the genes upregulated two folds and more were listed $(P<0.05)$. At last, the genes encoding the solute carrier proteins were grouped and the relation of alterations of gene expression levels with stemness of breast cancer was discussed.

\section{RESULTS and DISCUSSION}

Determination of target proteins to combat with drug resistant cancer stem cells requires revealing of significant alterations in gene expression levels, protein levels and epigenetic alterations on DNA sequences. In this study we focused on the SLC carrier proteins to exhibit their possible association with cancer drug resistance. The quality and concentration of RNA samples were appropriate to perform Human whole genome cDNA microarray analysis. After all experimental steps, the first quality control check (QC report) of signals obtained from GeneChips were in 'good' status. The genes that were upregulated two folds and more when compared to that of MCF-7 cells were determined and the statistically significant results were listed $(P<0.05)$. Table 1 demonstrates the overexpressed genes encoding SLC proteins in drug resistant BCSC-like cells. It is identified that 21 genes were up-regulated in BCSC-like cells with respect to parental drug responsive breast cancer cells. Also the functions of the proteins encoded by significantly up-regulated genes were presented schematically in Figure 1.

Table 1. Fold change values of SLC carrier protein coding genes (BCSC-like cells/ MCF-7 cells). The results were calculated from the statistically significant alterations between two groups $(P<0.05)$.

\begin{tabular}{|c|c|c|c|}
\hline Gene Name & Fold change & Common name & Description \\
\hline 234973_at & 35.35 & SLC38A5 & solute carrier family 38 , member 5 \\
\hline 210692_s_at & 33.70 & SLC43A3 & solute carrier family 43 , member 3 \\
\hline 206376_at & 28.34 & SLC6A15 & solute carrier family 6, member 15 \\
\hline 213664_at & 15.62 & SLC1A1 & $\begin{array}{c}\text { solute carrier family } 1 \text { (neuronal/epithelial high affinity glutamate } \\
\text { transporter), member } 1\end{array}$ \\
\hline 202499_s_at & 14.90 & SLC2A3 & solute carrier family 2 (facilitated glucose transporter), member 3 \\
\hline 205097_at & 13.96 & SLC26A2 & solute carrier family 26 (sulfate transporter), member 2 \\
\hline 228497_at & 9.861 & SLC22A15 & solute carrier family 22 (organic cation transporter), member 15 \\
\hline 202855_s_at & 8.897 & SLC16A3 & $\begin{array}{c}\text { solute carrier family } 16 \text { (monocarboxylic acid transporters), member } \\
3\end{array}$ \\
\hline 206600_s_at & 8.429 & SLC16A5 & $\begin{array}{l}\text { solute carrier family } 16 \text { (monocarboxylic acid transporters), member } \\
5\end{array}$ \\
\hline 219874_at & 8.228 & SLC12A8 & solute carrier family 12 (potassium/chloride transporters), member 8 \\
\hline 203908_at & 7.853 & SLC4A5 & solute carrier family 4 , sodium bicarbonate cotransporter, member 4 \\
\hline 234978_at & 7.690 & SLC36A4 & solute carrier family 36 (proton/amino acid symporter), member 4 \\
\hline 202234_s_at & 6.578 & SLC16A1 & $\begin{array}{c}\text { solute carrier family } 16 \text { (monocarboxylic acid transporters), member } \\
1\end{array}$ \\
\hline 217678_at & 3.981 & SLC7A11 & solute carrier family 7, (cationic amino acid transporter) member 11 \\
\hline 229065_at & 3.855 & SLC35F3 & solute carrier family 35 , member $\mathrm{F} 3$ \\
\hline 222528_s_at & 3.411 & SLC25A37 & solute carrier family 25 , member 37 \\
\hline 226217_at & 3.314 & SLC30A7 & solute carrier family 30 (zinc transporter), member 7 \\
\hline 230494_at & 2.555 & SLC20A1 & Solute carrier family 20 (phosphate transporter), member 1 \\
\hline 209402_s_at & 2.412 & SLC12A4 & solute carrier family 12 (potassium/chloride transporters), member 4 \\
\hline 244353_s_at & 2.294 & SLC2A12 & Solute carrier family 2 (facilitated glucose transporter), member 12 \\
\hline 227367_at & 2.035 & SLCO3A1 & Solute carrier organic anion transporter family, member 3A1 \\
\hline
\end{tabular}




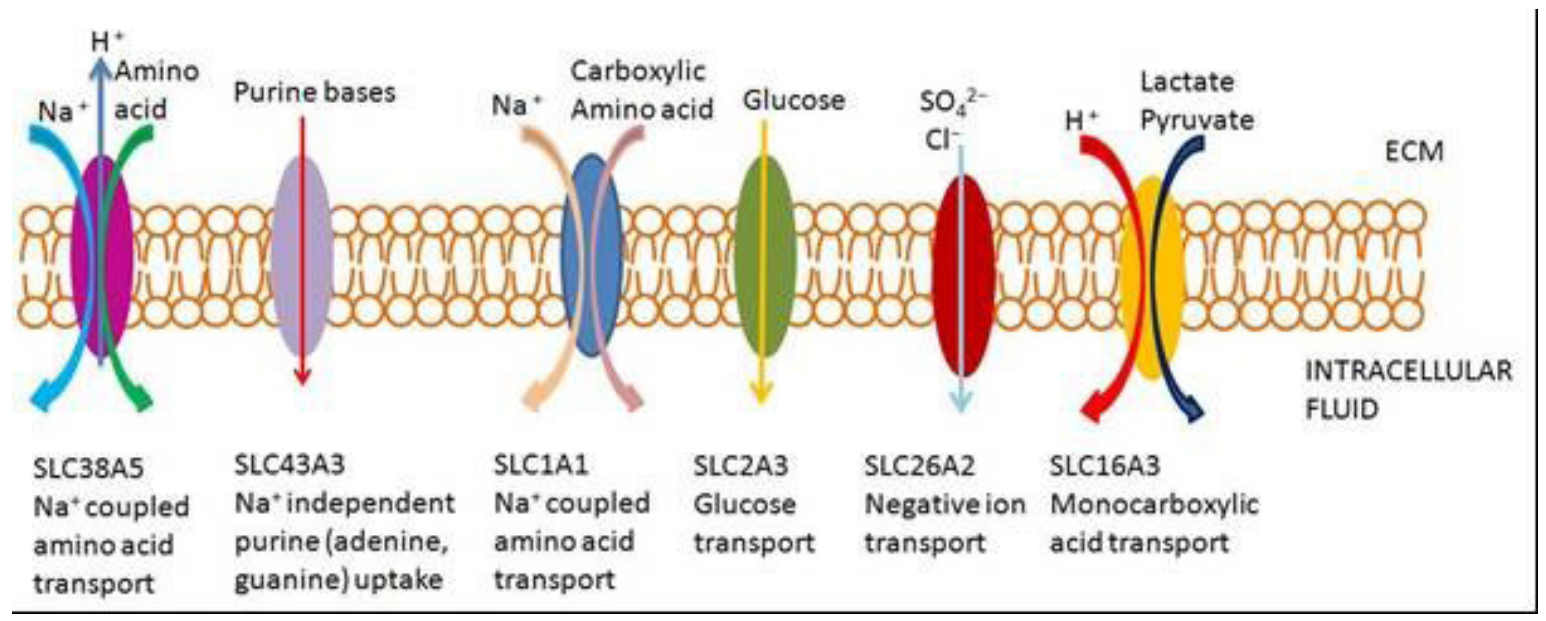

Figure 1. Illustration of the solute carrier proteins that are coded by the up-regulated genes; and their functions.

SLC38 is the carrier protein family of glutamine transporters. Glutamine transport into cells occurs by SLC38A5 as $\mathrm{Na}+$ coupled way. This is highly favorable by tumor cells to increase the intracellular $\mathrm{pH}$ due to high acidity in cancer cells [12]. This fact is in parallel with our findings. SLC38A5 encoding gene was upregulated about 35 folds in drug resistant BCSC-like cells. SLC43A3 takes role for cellular uptake of purine bases from extracellular matrix in to intracellular space. It facilitates use of purine bases for nucleotide synthesis. SLC43A3 is overexpressed about 33 folds in breast cancer stem cell-like cells when compared to drug sensitive cell line. Previously, SLC43A3 expression was correlated with angiogenesis and tumorigenesis [13]. SLC1A1 is a glutamate transporter gene and it was reported that colorectal cancer cells high SLC1A1 gene expression [14]. The authors claimed that changes in SLC1A1 expression may be correlated with colorectal cancer. In our study it is revealed that expression level of the gene that encodes SLC1A1 protein was increased in BCSC-like cells (15-16 folds) at the first time in literature. Glucose transporter family, SLC2A mediates glucose influx by facilitative diffusion. It was reported that SLC2A3 was associated with epithelial to mesenchymal transition (EMT) in cancer progression [15]. The paclitaxel resistant breast cancer cells used in our study also express EMT markers [16]. SLC26A2 is an ion channel for the transport of negatively charged ions. Dimberg et al. stated in their comprehensive study that SLC26A2 overexpression is observed in different tumor types compared with normal cells [17]. Also it was claimed that SLC26A2 may be highly correlated with aggressive breast cancer. Here we also found that SLC26A2 encoding gene was exp- ressed about 14 folds more in drug resistant BCSC-like cell line than drug sensitive parental MCF-7. SLC16A3 functions as membrane transporter for mono-carboxylic acids like lactic acid and pyruvic acid. Witkiewicz et al. reported that MCT4 encoded by SLC16A3 may be used as a marker for identification of breast cancer risk and SLC16A3 protein (MCT) inhibitors may be considered for treatment [18]. Here also we claim that SLC16A3 may be biomarker to target BCSCs.

We can conclude that this study covers alterations of expression levels of 21 SLC protein encoding genes in BCSC-like cells. Most of the findings are in concordance with the previous literature results performed with different cancer tissue types. Here, we reveal the association of the listed SLC coding genes with breast cancer stem cells for the first time. The carriers coded by the genes exhibited in Table 1 may be biomarkers for drug resistance and stemness of breast cancer. Some functional and mechanistic studies should be performed to progress with these proteins in future, for the development of new targeted therapy strategies.

\section{References}

1. E. Perland, R. Fredriksson, Classification Systems of Secondary Active Transporters, Trends Pharmacol. Sci., 38 (2017) 305-315.

2. M. Rask-Andersen, S. Masuram, R. Fredriksson, H.B. Schiöth, Solute carriers as drug targets: current use, clinical trials and prospective, Mol. Aspects Med., 34 (2013) 702-710. 
3. F.S. Liu, Mechanisms of chemotherapeutic drug resistance in cancer therapy-a quick review, Taiwan J. Obstet. Gynecol., 48 (2009) 239-244

4. M.D. Kars, Ö.D. İşeri, U. Gunduz, A.U. Ural, F. Arpacı, J. Molnar, Development of rational in vitro models for drug resistance in breast cancer and modulation of MDR by selected compounds, Anticancer Res., 26 (2006) 4559-4568.

5. M.D. Kars, Ö.D. İşeri, U. Gündüz, Drug resistant breast cancer cells overexpress ETS1 gene, Biomed. Pharmacother., 64 (2010) 458-462.

6. M.D. Kars, Ö.D. İşeri, U. Gündüz, A microarray based expression profiling of paclitaxel and vincristine resistant MCF-7 cells, Eur. J. Pharmacol., 657 (2011) 4-9.

7. M.D. Kars, G. Yıldırım, Determination of the Target Proteins in Chemotherapy Resistant Breast Cancer Stem Cell-Like Cells by Protein Array, Eur. J. Pharmacology, 848 (2019) 23 29.

8. M.D. Kars, Ö.D. İşeri, U. Gündüz, J. Molnar, Reversal of MDR by Synthetic and Natural Compounds in Drug Resistant MCF7 Cell Lines, Chemotherapy, 54 (2008) 194-200.

9. Ö.D. İşeri, M.D Kars, F. Arpacı, U. Gündüz, Gene Expression Analysis of Drug Resistant MCF-7 Cells: Implications for Relation to Extracellular Matrix Proteins, Cancer Chemoth. Pharm., 65 (2010) 447-455.

10. V. Tirino, V. Desiderio, F. Paino, G. Papaccio, M. De Rosa, Methods for Cancer Stem Cell Detection and Isolation, Somatic Stem Cells: Methods and Protocols, Methods Mol. Biol., 879 (2012) 32.

11. P. Valent, D. Bonnet, R. De Maria, T. Lapidot, et al., Cancer stem cell definitions and terminology the devil is in the details, Nat. Rev. Cancer., 12 (2012) 767-775.
12. Y.D. Bhutia, V. Ganapathy, Glutamine transporters in mammalian cells and their functions in physiology and cancer, Biochim. Biophys. Acta., 1863 (2016) 2531-2539.

13. N. Shimozono, M. Jinnin, M. Masuzawa, M. Masuzawa, et al., NUP160 SLC43A3 is a novel recurrent fusion oncogene in angiosarcoma, Cancer Res., 75 (2015) 4458-4465.

14. E. Pedraz-Cuesta, S. Christensen, A.A. Jensen, N.F. Jensen, et al., The glutamate transport inhibitor DL-Threo- $\beta$ Benzyloxyaspartic acid (DL-TBOA) differentially affects SN38and oxaliplatin-induced death of drug-resistant colorectal cancer cells, BMC Cancer., 15 (2015) 411.

15. M. Masin, J. Vazquez, S. Rossi, S. Groeneveld, et al., GLUT3 is induced during epithelial-mesenchymal transition and promotes tumor cell proliferation in non-small cell lung cancer, Cancer Metab., 29 (2014) 11.

16. Ö.D. İşeri, M.D. Kars, F. Arpacı, C. Atalay, I. Pak, U. Gündüz, Drug Resistant MCF-7 Cells Exhibit Epithelial-Mesenchymal Transition Gene Expression Pattern, Biomed. Pharmacother., 65 (2011) 40-45.

17. L.Y. Dimberg, C.G. Towers, K. Behbakht, T.J. Hotz, et al., A Genome-Wide Loss-of-Function Screen Identifies SLC26A2 as a Novel Mediator of TRAIL Resistance, Mol. Cancer Res. 15 (2017) 382-394.

18. A.K. Witkiewicz, D. Whitaker-Menezes, A. Dasgupta, N.J. Philp, Using the "reverse Warburg effect" to identify highrisk breast cancer patients: stromal MCT4 predicts poor clinical outcome in triple-negative breast cancers, Cell Cycle, 11 (2012) 1108-1117. 